Working Paper 8803

THE IMPACT OF FIRM CHARACTERISTICS

ON PLANT CLOSING DECISIONS

by Mary E. Deily

Mary E. Deily is a visiting economist at the Federal Reserve Bank of Cleveland and an assistant professor of economics at Texas A\&M University. The author would like to thank Paul Bauer, Richard E. Caves, and Erica L. Groshen for helpful comments.

Working papers of the Federal Reserve Bank of Cleveland are preliminary materials circulated to stimulate discussion and critical comment. The views stated herein are those of the author and not necessarily those of the Federal Reserve Bank of Cleveland or of the Board of Governors of the Federal Reserve System.

June 1988 
The Impact of Firm Characteristics on

Plant Closing Decisions

\section{I_ Introduction}

The familiar debate about the effect of market structure on efficiency has taken a new twist in recent analyses of firm behavior during an industry's decline. Few economists would expect such firm characteristics as size or extent of diversification, to determine which plants survived a contraction. Rather, regardless of the owning-firms' characteristics, they would expect high-cost plants with older capital to shut down, because these plants earn the least quasi-rent and require replacement investments sooner. Setting aside the possibility of firm economies of scale, an owning firm should not affect this outcome.

But game-theory analyses of contraction have discovered different possibilities. If a firm can convince its rivals that its plants will remain open, the other firms might be forced out of the market. Normally, a firm would ignore a rival's threat to continue operating higher-cost capacity, and it is difficult to see how any such threat could ultimately alter a contraction pattern. But recent studies of exit decisions suggest that such firm characteristics as size or number of plants, unrelated to plant-level production costs, may affect the order of plant closings (Ghemawat and Nalebuff, [1985]; Whinston, [1987]). In these models, such characteristics increase the crediblity of a firm's threat to remain in the market regardless of current losses, thus forcing other firms to reduce capacity first.

I $n$ these models, demand ultimately declines to zero. Thus the analyses indicate possible effects an owning firm can have on the order of plant closings only; there is no question of any plant surviving in the long run. 
But some of the authors of the analyses discussed here suggest that one might apply their models to industries undergoing severe, though not complete, contraction.

This paper examines the plant-closing decisions integrated steel firms in the United States made from 1977 to 1987, a decade of significant contraction, to determine whether firm characteristics have influenced either the probability of a plant's closing or the timing of its closing. A sample of 49 steel plants, which includes almost all the carbon steelmaking capacity owned by integrated firms in 1976 is identified. Using a logit estimation model, the influence of plant and firm characteristics on the probability of a plant surviving through 1987 is assessed.

The variables used to capture important differences in the plants include proxies for (1) shifts in demand for their products; (2) their production costs relative to other plants; and (3) the age of their capital stock in 1976. Under basic exit theory, variation across plants in these characteristics should determine which plants close. In addition, some firm-related variables, including the size of the owning firm, whether the firm owns more than one plant, and the firm's degree of diversification, are included to determine their influence on a plant's probability of closing, all other factors held equal.

The resulting equations are estimated using a logit model, with the dependent variable equal to zero if the plant was still open in 1987, and equal to one if it had closed. Then, the residuals generated by estimating the various specifications are examined for evidence that firm characteristics affect the order of exit. The number of years a plant had been closed as of the end of 1987 is regressed on the estimated probability of a plant's exit as well as on variables that represent the owning-firm's characteristics. 


\section{Theory}

In a contracting industry where firms are price-takers, those plants with lower expected revenues, higher costs, and older capital should close first, because they earn the least quasi-rent and require major replacement investment sooner. The following paragraphs, however, discuss several avenues by which firms might alter either the order of exit or the ultimate survival of a plant.

First, firm economies of scale may influence a plant's probability of closing. If these economies exist, the plants owned by larger firms would, ceteris paribus, experience lower costs, providing them an advantage over plants owned by smaller firms.

Second, a firm might be able to convince its rivals that it will remain in the business regardless of their plant-closing decisions. To make such a threat credible, the firm would have to convince rivals of its willingness and ability to sustain losses if its rivals do not exit. Drawing on the literature analyzing wars of attrition, Ghemawat and Nalebuff (1985) developed a model in which the credibility of the threat depends on the firm's size.

In this model, an industry consists of two single-plant firms (firm 1 and firm 2) facing a smoothly declining demand curve. The firms always operate at full capacity, and each firm knows its rival's costs. They assume subgame perfection, so that only credible threats work. The time of optimal exit for a firm alone in the market is the point at which demand exactly equals plant capacity. Thus, after demand falls below the capacity of the combined firms, the larger firm 1 would, if firm 2 stays in, take losses and then exit at $\mathbf{t l}$, or if firm 2 exits, earn monopoly profits and exit at tl. 
But firm 2 can operate profitably in the industry until t2. As long as firm 2 expects to make enough monopoly profit between $\mathrm{tl}$ and $\mathrm{t} 2$ (the period after firm 1 will have exited in any case, but before firm 2 must exit) to cover the losses incurred after the break-even point when both firms still operated, it will remain in the market. Since the larger firm cannot credibly threaten to stay in the market after tl, it will avoid useless losses by exiting immediately when the break-even point for the industry at its original total capacity is reached.

Ghemawat and Nalebuff (G\&N) demonstrate that even if scale economies give the large firm a sizable cost advantage, it will exit first. Their model includes firms with either one plant, or several plants of the same size. Extending this model to more complex cases, Whinston (1987) found that, while firm size may well influence strategic behavior, one cannot safely assume the simple result that the largest firmwill exit first. As G\&N showed, a firm's ability to force rivals out with threats to maintain capacity depends on the timing of a firm's plant-closing decisions if it were alone in the market, and this timing, in turn, depends on the number and size of the firm's plants compared to those owned by its rivals. Though strategic behavior certainly exists, no easy rule can be derived relating exit behavior to firm or plant size, much less to plant costs.

Third, other possible mechanisms for establishing a credible commitment to the remaining market might also exist. For one thing, as G\&N pointed out, if capital constraints exist, they could affect the order of exit, much the way firm size does, by determining which firm could credibly threaten to incur losses. In this case, the constrained firm would exit first.

Alternatively, capital constraints on some firms could influence which plants survived a contraction. To affect the probability of a plant's 
ultimate survival, these constraints would have to ensure that a firm's profit maximizing-option would be to close its plants permanently rather than sell them. Even if the firm went bankrupt because of capital constraints, these constraints would not affect the plant, unless neither the firm nor any buyer untertook to operate it.

It has also been suggested that single-plant firms or undiversified firms might be less willing to close plants, because of a relatively greater susceptibility to agency problems in this particular situation. If those making plant-closing decisions in such firms have low opportunity costs, perhaps attributable to specific human capital, then they might, ceteris paribus, hesitate to close their plants.' For non-profit-maximizing decisions to persist, of course, the market for corporate control must fai 1.

\section{Specification and Data}

\section{A. Specification}

Ideally, one would study the decisions steel firms make about which plants to close, and when to close them, with panel data detailing the expected profitability of each plant each year and the condition of the owning-firm each year. But because the contraction extended over a prolonged period, only a few plant closings occurred in a year, which limited the possibilities for using time-series as well as cross-section data.

Instead, the industry's plant-closing decisions are studied in these two steps. First, a cross-section of data on each plant is used to estimate the probability of each plant closing, where the dependent variable is zero if the plant remained open, and one if it closed. The independent variables include the information about each plant that neoclassical exit theory specifies as 
important: each plant's long-run expected revenues and costs, and the age of its capital stock. In addition, several different sets of variables are tested as proxies for the various firm effects suggested.

When one compresses what is actually a process occurring over an extended time into a cross-section, one loses information about changes over time in the plants' relative standing and in the status of the owning-firm. The nature of the changes in competitive conditions taking place make the relative profitability of steel plants during this period appear to have been largely determined by such stable factors as plant location and product mix, implying that a relatively profitable plant in 1977 would still be relatively profitable in $1987 .^{2}$ Those variables that depend on time are measured in the year 1976, the year before the first major plant closings occurred.

Similarly, all information about the firms derives from 1976 . Thus, the estimates indicate how a firm's initial position might affect its subsequent plant-closing decisions. It is possible that, by changing size or by other strategic maneuvers during the period, firms introduced new elements that took effect at different times. If, however, advantages that can permanently affect a plant's viability are attached to particular firm configurations, then those firms initially possessing such characteristics should, ceteris paribus, be less willing to close their plants, and the estimated coefficients should capture the entire effect.

Thus, the probability of a plant closing between 1977 and 1987 is estimated on cross-section data, and the effect of firm characteristics on this probability is evaluated. The estimated probabilities are then used in the second step of the investigation, in which the effect of firm characteristics on the order of closings is examined.

A regression of the number of years a plant has been closed on the estimated probability of a plant's closing provides information on the order 
of plant closings. With the estimated probability of closing held constant, the various firm characteristics included in this regression indicate the influence these factors have on the speed with which a plant closes.

Thus, the first requirement is to isolate variables that capture the important differences in relative long-run profitability among plants. Two variables, COAST and SHAPES, capture the relative impact across plants of the growth of import and minimill competition. The variable COAST is zero for inland plants, and one for plants on a coast. Since the transportation costs for imported steel are lower in these areas, coastal plants are expected to be at a relatively greater disadvantage versus imports, and thus to have lower expected revenues. The coefficient of this variable should be positive.

The variable SHAPES represents the percentage of the plant's hot-rolling capacity devoted to plates, bars, structural shapes, and other heavy shapes. Plants producing these products are assumed to face a relatively larger decrease in demand. Minimills produce some of these products, and others are produced for industries, like shipbuilding or railroads, that are themselves undergoing contraction. Since during the period under examination these product markets should have been particularly competitive, the coefficient of this variable should be positive.

In addition to expected revenue, cost variations among plants should influence the firms' closing decisions. Two variables, LG(PSIZE) and EARC, represent these variations. The variable LG(PSIZE), the log of a plant's raw-steel capacity, captures cost variations across plants. Since significant economies of scale exist in this industry, larger plants are expected to have lower costs, thus raising their profitability relative to smaller plants. The log of PSIZE is used under the assumption that the disadvantage of the smaller 
plants relative to the largest is greater than their disadvantage relative to medium-sized plants. ${ }^{3}$ The coefficient of this variable is expected to be negative, as a larger size reduces the probability of closing, ceteris paribus. ${ }^{4}$

A dummy variable, EARC, controls for a basic difference in technology among the plants in the sample. Four of the plants used only electric-arc steel furnaces in 1976, which reduced their disadvantage against minimills and imports as well as reducing the possible gains from economies of scale. Thus, these mills should be less likely to exit, and the sign of the coefficient should be negative.

Finally, a variable, LG(AGE), controls for differences in the ages of the plants' capital stocks. If, in a contracting industry, the plants were otherwise identical, the oldest ones would exit first because their reinvestment decisions would arise first. The variable LG(AGE) represents the log of the percentage of the plant's capital stock for which new investment was announced after 1959 but before 1977. Since plants containing more later-vintage capital can operate longer without making major replacement investments, mills with younger capital in 1976 are expected to have a lower probability of exit during the industry's contraction.

The log of the percentage is used because varying depreciation rates among different types of equipment, and the truncated nature (no pre-1960 investment information) of the data used, made differences among plants that received no investment and those that received some appear to be more important than differences between those that received some investment and those that received a lot. The sign of the coefficient should be negative, since a plant with a greater percentage of newer capital is likelier to remain open. 
In sum, these five variables capture all the important variation among plants attributable to a plant itself, and they represent relative expected revenues, relative production costs, and the relative ages of capital stocks in the mid-1970s. The following variables are adopted as proxies for firm characteristics: First, the firm's annual raw steel capacity in 1976, FSIZE, represents firm size, a significant variable if either firm economies of scale or the G\&N analysis relating the abi 1 ity to make a credible threat to firm size affects the probability of exit among steel plants. ${ }^{5}$

Since, however, Whinston's (1987) analysis indicates that size alone does not determine strategic advantage in more complex industry configurations, two alternative sets of variables are used to capture the influence of both the owning-firm's size and number of its plants on the probability of a plant's closing. First, a set of dummy variables, D1-D6, is included to control for the number of plants. If firms with a particular number of plants have an advantage, then the coefficient of their group dummy wi 11 be negative and significant.

Since firm size and number of plants are correlated, this grouping roughly controls for both firm size and plant number, although some examples of smaller multi-plant firms and larger single-plant firms did appear. Therefore, the model is reestimated with an alternative set of dummies, DA-DE, that represent groups of firms sorted first by size and then by number of plants in 1976. If a particular configuration of firm size and number of plants affected the probability of plants' survival, the coefficient of that group should be significant.

Finally, two additional variables, UNDIV and ONE, test for the possibility that capital constraints or agency problems affected plant-closing decisions 
in the steel industry. The variable, UNDIV, is the dollar value of a firm's sales of steel products in 1976, divided by its total sales in 1976 . It is assumed to be positively correlated with both a firm's inability to access internal cash flows unaffected by the industry's decline and to the likelihood that senior management will tend to resist plant-closing decisions. If a more diversified firm uses funds from deep pockets to subsidize its steel capacity, then the plants it owns should be less likely to exit. Thus, the coefficient of UNDIV, which increased with the firm's specialization, should be positive.

Alternatively, a diversified firm might be more likely to close its steel plants if its management expects to lose less by the closures, a situation that would produce the opposite sign for the coefficient of UNDIV. In addition, the dummy variable, ONE, which is one for single-plant firms and zero for multi-plant firms, is also included to control for differences in the probability of closing that might occur because of a management's unwillingness to close its only steel plant. ${ }^{6}$

Three specifications are estimated:

(1) $P=f(C O A S T$, SHAPES, EARC, LG(AGE), LG(PSIZE), FSIZE, ONE, UNDIV)

(2) $P=f(C O A S T$, SHAPES, EARC, LG(AGE), LG(PSIZE), UNDIV, D1, D2, D3, D4, D5, D6)

(3) $P=f($ COAST, SHAPES, EARC, LG(AGE), LG(PSIZE), UNDIV, G1, G2, G3, G4, G5, G6). 


\section{B. Data}

The sample is a set of 49 steelmaking plants owned by integrated producers in the mid-1970s. While not all of the plants were integrated, each firm owned at least one integrated plant. A plant 'closed' when its steelmaking furnaces shut down, and 19 of the plants closed during the period under study. In addition, three other plants that experienced capacity reductions of over 65 percent were included among exited plants, bringing the total closed to 21 , or 43 percent of the sample. Table 1 lists the plants, their owning-firms, and their open or closed status as of the end of 1987.

Plants located on or near the East, West, or Gulf Coasts have a value of one for the dummy variable COAST; all others have a value of zero.

The variable, SHAPES, represents the percentage of hot-rolled capacity that produced plates, structural shapes and pilings, and hot-rolled bars and bar shapes. The capacity data derives from the early 1960s, the last period for which detailed product data was published. A plant's size, PSIZE, is its annual raw-steel capacity in 1976, as reported by the Institute for Iron and Steel Studies (IISI, 1979).

To calculate the vintage of the plant's capital stock, the percentage of the capacity in each of four major departments (coke-making, blast furnace, steel furnace, and primary rolling or continuous casting) that had been replaced after 1959 was calculated.' This sum was then divided by the number of these departments the plant operated. Thus, this figure measures the amount of reinvestment that had taken place, corrected for the number of these departments located at the plant and for the size of the replacement within each department.

The variable FSIZE represents the annual raw-steel capacity of the firm in 1976 as reported by the IISI (1979), excluding the plants omitted from the 
sample. (Table 2 lists each firm, its size, and the number of its plants included in the sample. Table 2 also includes a list of the members of each set of groups.) The variable UNDIV represents the ratio of steel sales to total sales reported by the corporation owning the plants in its annual report of 1976 .

\section{Empirical Evidence}

\section{A. Probit Estimation Results}

Table 3 presents the estimates of equations 1 through 3 . In addition, column 4 shows the results of estimating the closing probabilities with the plant variables alone. With the exception of LG(PSIZE) in equation 3 , the coefficients of the plant-characteristic variables all have the predicted sign.

The coefficients of COAST and SHAPES are positive and significant, indicating that location and product mix were important factors in determining the probability that a plant would close. As expected, the coefficients indicate that plants located on a coast or specializing in steel shape production were more likely to close.

The coefficient of EARC is always negative and is significant in equation 4. The sign of the coefficient indicates that, all other factors being equal, electric-arc-based plants were likelier to remain open than other plants. Overall, the strength of the results is surprising--especially since only four electric-arc-based plants appeared in the sample--two of the four closed. In equations 2 and 3 , in particular, the small t-statistics may be the result of very small samples: The coefficient in these equations estimates the effect of using electric-arc technology on a plant's probability of closing within each group, and the number of such plants in each group is, in most cases, zero or one. 
The coefficient of LG(AGE) is, as expected, negative, but not significant except in equation 3 . The results imply that, over the entire sample, the probability of exit is increased by an older vintage of capital, though not significantly. But when the sample is grouped by firm and plant size, vintage becomes significant, implying that the age of the capital stock affects the relative probability of a plant's exit for plants owned by firms of similar size and with about the same number of plants.

The coefficient of LG(PSIZE) is negative and significant only in equation 4, the equation that does not include firm-size variables. Since 20 percent of the firms own only one plant, and since larger firms tend to own larger plants, the inclusion of firm size reduces the significance of LG(PSIZE). This effect appears most strikingly in equation 3, which indicates that the effect of LG(PSIZE) among firms grouped by size and number of plants is negligible.

Overall, the characteristics of a plant appear to influence strongly the probability of its closing. When all of the firm variables are excluded (as in equation 4), all plant characteristics except LG(AGE) become significant. In the first three equations, the coefficients of EARC and of LG(PSIZE) are not significant, probably because of the small sample in the case of EARC and correlation with the grouping in the case of LG(PSIZE). The coefficients of COAST and of SHAPES remain significant in these three equations, however, indicating the importance of plant location and product mix for plants owned by all types of firms.

Evidence that firm characteristics influence the probability of a plant's closing is less clear. The coefficient of FSIZE is negative, indicating that larger firm size may reduce the probability of exit, perhaps because of firm scale economies. But the coefficient is small and is not significant. 
The coefficient of the dummy variable ONE is also negative, indicating that plants owned by single-plant firms are less likely to exit than all other plants; however, this coefficient is also insignificant.

The coefficient of UNDIV, is negative, relatively large, and significant in equation 3. These results indicate that plants owned by the more diversified firms may, all other factors being equal, be more likely to close, but that this effect is particularly strong among firms of similar size with similar numbers of plants.

The two sets of group variables, which classify firms in equation 2 by number of plants and in equation 3 by the number of plants and firm size, provide clearer evidence that a firm effect may exist. In both equations, the omitted group is a single-firm group consisting of the largest firm with the most plants: United States Steel (USX). The coefficients reported for the group dummies thus estimate the difference in the probability of a plant closing when owned by firms within the group as compared to the probability of those owned by USX closing.

In equation 2, the estimated coefficients indicate that firms with two or three plants, as opposed to those with one or with more than three, were more likely to close plants than was USX, all other factors being equal. It could be that group 2 and group 3 plants are smaller on average than those in other groups, or the firms in these groups could be smaller on average. But neither of these possibilities appears to be the case, as the following table shows: 


\begin{tabular}{lcc} 
& $\begin{array}{c}\text { Mean Plant } \\
\text { Group }\end{array}$ & $\begin{array}{c}\text { Mean Firm } \\
\text { Size }^{*}\end{array}$ \\
\cline { 2 - 2 } D1** $^{* \star}$ & 2.64 & 2.64 \\
D2 & 2.20 & 4.40 \\
D3 & 3.43 & 10.28 \\
D4 & 2.10 & 8.47 \\
D5 & 2.32 & 11.60 \\
D6 & 4.23 & 25.40 \\
USX & 3.42 & $\underline{41.08}$ \\
Total & $\mathbf{3 . 1 1}$ &
\end{tabular}

\footnotetext{
*Millions of tons of raw steel capacity. Institute for Iron and Steel studies (1979) and table 2

**IfInland Steel is classified as a separate group, the mean plant and firm size of this group is 2.08 .
}

Source: Institute for Iron and Steel Studies (1979); and table 2.

Rather, these results seem to indicate the existence of a strategic disadvantage for firms of this configuration, since they suggest that these firms were more likely to close plants, even after controlling for variation in the plants' expected revenues, costs, and ages.

The results of equation 3 provide some evidence that this disadvantage lies in the number of plants rather than in firm size. When the groupings are altered to reflect firm size and number of plants, the estimated coefficients indicate that only the two plants in Group DB, the Wheeling-Pittsburgh firm, are more likely to close than plants owned by USX. Given that the group is a single firm, one can interpret this as only slight evidence of an increased probability of closing for plants owned by a small multi-plant firm.

In summary, there is some evidence that a firm effect exists when firms are grouped by number of plants. The estimated coefficients of D2 and D3 may indicate an inherent disadvantage for firms owning only two or three plants, a disadvantage that single-plant firms somehow manage to avoid. This disadvantage does not appear to stem from either smaller plant size or smaller firm size, as the estimated coefficients for groups with both larger and smaller average plant and firm sizes provide no evidence of a higher or lower probability of closing for plants in those groups. 


\section{B. Discussion}

The probit results can be used to evaluate the validity of the various theories of owning-firm effects for the U.S. steel industry. First, there is no evidence of a strong relationship between an owning-firm's size and probability of its plants closing. Larger firms were not more likely to close plants, which rules out, for this industry, strategic exit behavior based solely on firm size. But the evidence for firm economies of scale is also weak. Overall, there appears to be no systematic relationship between firm size and the probability of a plant closing once one controls for plant characteristics.

Second, little evidence appeared indicating that agency problems affect the plant-closing decisions of single-plant firms in particular. While the results of equation 1 indicate that the probability of such plants closing may be smaller than for all other plants, equations 2 and 3 indicate that the probability may be greater than the probability of USX closing its plants. Thus, these estimates reveal no significant tendency by single-plant firms to avoid closing.

Third, there is no evidence that diversified firms use funds from deep pockets to subsidize high-cost capacity. Rather, the evidence indicates that these firms are more likely to close their plants than more specialized firms. Possibly the degree of a firm's diversification provides a better measure of its management's opportunity cost than the single-plant dummy, and the estimated coefficient may thus reflect an agency problem, that of specialized managements delaying plant closings. On the other hand, the sign of this coefficient may reflect the high cost of closing steel mills. These enormous closing costs involve both immediate outlays and ongoing expenditures 
(Deily, 1988), and specialized firms may well hesitate to close plants for fear of bankrupting themselves.

Finally, the coefficients of the group dummies indicate that the number of plants may be a more important strategic variable than firm size. In this industry, firms that owned two or three plants in 1976 appear to have been at a disadvantage during the ensuing contraction.' of course, the plants these firms own may share some characteristic other than those controlled for that puts them at a disadvantage. But no such characteristic is immediately obvious.

Overall, except for a possible strategic disadvantage related to number of plants, the evidence for a firm effect altering the probability of a plant closing is not strong. The results of equation 4 show that the model loses little of its predictive power when these variables are excluded. (Table 4 lists the prediction errors for equations 2 and 4.$)$ In addition, the restriction that the coefficients of all the firm characteristic variables equal zero may be accepted statistically. While low t-statistics do not necessarily exclude a variable from a model, in the steel industry the characteristics of each plant much more than those of its owning-firm appear to determine the probability of it closing.

Before turning to an examination of the order of plant exit, a more subtle avenue of influence for firm size is examined. A systematic 'firm effect' may arise if the historical decisions made by firms about where to locate plants, which product mix to produce, or what size plant to build are correlated with firm size. Interestingly enough, regressing the variable FSIZE on the remaining plant variables shows that larger firms tend to own larger plants and to specialize in the production of shapes. (See table 5,) Some evidence also suggests that larger firms are more likely to have built coastal plants, 
and that their plants may have older capital. But these variables are not significant.

\section{Analysis of Order of Exit}

This section analyzes YEAR, the number of years that each plant has been closed. The values taken by YEAR range from zero, for all those plants still open in 1987, to 11, for those plants that exited in 1977 . Using a tobit estimating procedure, this variable was regressed on the predicted probabilities of closing for each plant as calculated from the estimates reported on table 3 and the three sets of firm characteristic variables. The coefficient of the estimated probability of closing was positive and significant in all cases, while none of the coefficients for the firm characteristic variables was ever significant.

But the inclusion in the sample of plants that remain open could have heavily influenced these results; that is, the estimated coefficients may be explaining the qualitative open-closed aspect of the data rather than the number of years a plant has been closed. Therefore, an additional set of estimates was calculated for the sample of closed plants only. ${ }^{9}$

In general, the results are disappointing. The coefficient of the estimated probability of exit is almost always insignificant, as are the coefficients of the firm characteristics variables. As table 6 shows, the best results occur when the firm characteristics variables used are the set of 'number of plants' dummies. Column 4, which uses the estimated closing probability based only on plant characteristic, P4, shows that this probability is positive and significant, indicating that among firms with the same number of plants, the plants with the higher probabilities of closing exit sooner. 
Some weak evidence also suggests that, after controlling for the probability of a plant exiting, specialized firms closed their plants more quickly, that single-plant firms closed their plants more quickly than USX, and that Republic Steel (the only firm owning five plants in 1976) closed its plants slower than USX. The results for D3 (in table 6, column 4) indicate that firms in this group appear most likely to close their plants more quickly than USX only when the apparent disadvantage of being a three-plant firm in 1976 is not included in the estimated probability of closing. None of these coefficients, however, is significant at the 10-percent level for a two-tailed t-test; and in sum, the results yielded little evidence that either a plant's characteristics or its owning-firm's status in 1976 explains the order in which plants closed.

\section{v. Conclusions}

A simple set of plant characteristics can explain which plants closed during the steel industry's contraction. The estimates indicate that plants located near a coast, plants specializing in products more likely to be produced by minimills, and small plants, were most likely to close. Larger plants, located inland, that produce flat-rolled products, were least 1ikely to close, as were electric-arc-based plants. These five variables together accurately predicted the status of 86 percent of the plants.

Some evidence also suggests that certain owning-firm characteristics measured before the start of the contraction affected the probability of a plant's survival. The size of the owning-firm did not appear to affect the probability of a plant closing, implying that G\&N's model of strategic exit behavior does not explain the steel industry's experience. But firms owning 
just two or three plants, as opposed to only one or more than three, may have been at a disadvantage in this industry. The plants owned by these firms had, all other factors being equal, a higher probability of closing.

These coefficients may reflect some strategic disadvantage related to this particular firm configuration in the steel industry, or the effect of some plant characteristic omitted from the estimated equations. Some evidence for the later possibility lies in the apparent historical tendency in the steel industry for firms of similar types to make similar long-run decisions about such matters as plant location and product mix. While studies of plant-closing patterns in other declining industries might help to sort out these two hypotheses, it seems clear for now that models of strategic behavior in contracting industries should include the number of a firm's plants as an important variable.

Some tentative evidence also suggests that specialized firms are more likely to keep their plants in operation. This tendency may reflect either agency problems resulting from specialized management with low opportunity costs or capital constraints working in an unusual direction--that is, specialized firms may be more inclined to keep their plants open because they cannot afford to close them. Most strikingly, no evidence emerged to indicate that diversified firms use their deep pockets to subsidize plants.

Finally, while plant characteristics, as embodied in estimated closing probabilities, and characteristics of owning-firms as of 1976, may affect the speed with which plants closed between 1977 and 1987, the estimated coefficients for these variables were almost never significant and a great deal of unexplained variance appeared. Part of this poor estimated-closing-probabilities performance resulted from excluding all the information from plants still open. But most of the problem probably lies in 
the cross-sectional nature. of this analysis. While such relatively stable factors as plant location, product mix, and size perform well in determining which plants eventually close, changes that occurred over time in plant profitability and in firm characteristics, which were ignored in this analysis, might provide more insight into the order of plant closings. 


\section{Firm}

Bethlehem

Republ i c

Bethl ehem

Bethl ehem

Bethl ehem

United States Steel

Jones \& Laughlin

Jones \& Laughlin

United States Steel

United States Steel

United States Steel

Sharon

Wheeling-Pittsburgh

Armco

Jones \& Laughlin

Republ ic

Republ ic

United States Steel

United States Steel

Youngstown Sheet \& Tube

Youngstown Sheet \& Tube

Wheel ing-Pittsburgh

Bethlehem

Inland

United States Steel

Youngstown Sheet \& Tube

National

Republic

United States Steel

Interlake

National

McLouth

Armco

Bethl ehem

National

Armco

Republic

United States Steel

Armco

United States Steel

Lone Star

United States Steel

United States Steel

Kaiser

CF\&I

Cyclops

Ford

International Harvester

Alan Wood $\underline{\text { Plant }}$

Lackawanna, NY

Buffalo, NY

Bethlehem, PA

Johnstown, PA

Steelton, PA

Fairless, PA

Aliquippa, PA

Pittsburgh, PA

Dusquesne, PA

Braddock, PA

Homestead, PA

Farrell, PA

Monessen, PA

Middletown, $\mathrm{OH}$

Cleveland, $\mathrm{OH}$

Cleveland, 어

Warren, $\mathrm{OH}$

Lorain, $\mathrm{OH}$

Youngstown, $\mathrm{OH}$

Youngstown, $\mathrm{OH}$

Campbe 11, OH

Steubenville, or 0

Burns Harbor, IN 0

Indiana Harbor, IN 0

Gary, I N

Indiana Harbor, IN 0

Granite City, IL 0

South Chicago, I L

South Chicago, IL

Riverdale, Chicago, I L 0

Great Lakes, MI 0

Trenton, MI 0

Kansas City, MD 0

Sparrows Point, MD 0

Weirton, WA 0

Ashland, KY 0

Gadsden, AL 0

Fairfield, AL 0

Houston, TX

Baytown, TX

Lone Star, TX

Geneva, UT

Torrance, CA

Fontana, CA

Pueblo, $\infty$

Portsmouth, OH

Dearborn, M I

South Chicago, IL

Conshohoken, PA

0

0

1

1

1

0

1

0

0

0

1

1

(1)

(1)

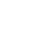

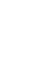

$1^{*}$

*The closing of all basic-oxygen furnaces or open-hearth furnaces reduced capacity by over 65 percent.

Source: Wharton Econometrics (1987); Hogan (1984, 1987); various annual reports; and the author. 
Firm

Alan Wood Steel

Armco

Bethlehem Steel

CF\&I

Cyclops

Ford Motor Co.

(Rouge Steel)

Inland Steel

Interlake

International Harvester (Wisconsin Steel)

Jones \& Laughlin

Kaiser Steel

Lone Star Steel

McLouth Steel

National Steel

Republic Steel

Sharon

United States Steel

Wheeling-Pittsburgh

Youngstown Sheet \& Tube

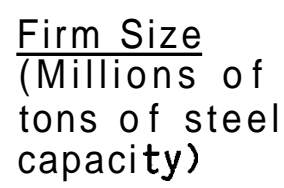

Number of Plants

1.50

9.90

25.40

1.67

1.00

3.75

8.20

.90

1.20

8.74

4.00

1.50

3.40

13.10

11.60

1.90

41.08

4.40

9.00
1
4
6
1
1

1
1

1

3

1

1

1

3

5

12

2

3

Source: Institute for Iron and Steel Studies (1979). 
Table 2 (Cont.)

\section{Groups D1-D6 (Number of Plants)}

D1

D2

D3

D4

D5

D6

Groups DA-DE (Firm Size and Number of Plants)

$\mathrm{DA}$

$\mathrm{DB}$

DC

DD

$\mathrm{DE}$
Alan Wood, CF\&I, Cyclops, Interlake, Lone Star, Sharon, International Harvester, Ford, Kaiser, McLouth, Inland*

Wheeling-Pittsburgh

Jones \& Laughlin, National, Youngstown Sheet \& Tube

Republic

Armco

Bethlehem

*As alternative specifications, Inland was classified as a separate group. The estimation results did not change significantly.

Source: Author. 
Table 3

Dependent Variable: 1 if plant closed*

(1) (2) (3)

$\begin{array}{llll}4.13 & 1.58 & 1.20 & 1.15 \\ (1.80) & (.56) & (.44) & (1.03)\end{array}$

\begin{tabular}{|c|c|c|c|c|}
\hline COAST & $\begin{array}{r}3.04 \\
(2.10)\end{array}$ & $\begin{array}{c}3.30 \\
(1.77)\end{array}$ & $\begin{array}{r}3.85 \\
(2.04)\end{array}$ & $\begin{array}{c}2.35 \\
(1.89)\end{array}$ \\
\hline HEAWY & $\begin{array}{c}4.79 \\
(2.66)\end{array}$ & $\begin{array}{c}8.49 \\
(2.86)\end{array}$ & $\begin{array}{c}8.61 \\
(2.62)\end{array}$ & $\begin{array}{c}3.51 \\
(2.54)\end{array}$ \\
\hline LG(AGE) & $\begin{array}{c}-.43 \\
(-1.24)\end{array}$ & $\begin{array}{c}-.63 \\
(-1.40)\end{array}$ & $\begin{array}{c}-.83 \\
(-1.85)\end{array}$ & $\begin{array}{l}-.26 \\
(-.89)\end{array}$ \\
\hline LG(PSIZE) & $\begin{array}{l}-1.48 \\
(1.37)\end{array}$ & $\begin{array}{l}-1.17 \\
(-.90)\end{array}$ & $\begin{array}{l}.08 \\
(.06)\end{array}$ & $\begin{array}{l}-2.06 \\
(-2.35)\end{array}$ \\
\hline EARC & $\begin{array}{l}-3.32 \\
(-1.66)\end{array}$ & $\begin{array}{l}-1.89 \\
(-.62)\end{array}$ & $\begin{array}{l}-2.88 \\
(-1.18)\end{array}$ & $\begin{array}{l}-3.21 \\
(-1.80)\end{array}$ \\
\hline FSIZE & $\begin{array}{r}-.05 \\
(-1.12)\end{array}$ & & - & - \\
\hline UNDIV & $\begin{array}{l}-3.24 \\
(-1.50)\end{array}$ & $\begin{array}{l}-4.36 \\
(-1.51)\end{array}$ & $\begin{array}{l}-5.24 \\
(-1.72)\end{array}$ & \\
\hline ONE & $\begin{array}{c}1.14 \\
(-.81)\end{array}$ & & - & - \\
\hline DIIDA & - & $\begin{array}{l}1.77 \\
(.83)\end{array}$ & $\begin{array}{l}3.14 \\
(1.16)\end{array}$ & - \\
\hline $\mathrm{D} 2 / \mathrm{DB}$ & - & & & - \\
\hline D3/DC & - & $\begin{array}{l}3.30 \\
(1.78)\end{array}$ & $\begin{array}{l}.69 \\
(.32)\end{array}$ & - \\
\hline D4 & - & $\begin{array}{l}-2.25 \\
(-.57)\end{array}$ & - & - \\
\hline D5/DD & - & $\begin{array}{l}2.09 \\
(.88)\end{array}$ & $\begin{array}{l}2.82 \\
(1.55)\end{array}$ & \\
\hline D6/DE & - & $\begin{array}{l}-2.71 \\
(-1.34)\end{array}$ & $\begin{array}{l}-2.46 \\
(-1.26)\end{array}$ & \\
\hline $\begin{array}{l}\text { Log Likelihood } \\
\% \text { Correct }^{* *}:\end{array}$ & $\begin{array}{l}:-20.772 \\
83.67\end{array}$ & $\begin{array}{l}-15.955 \\
89.80\end{array}$ & $\begin{array}{c}-17.215 \\
89.80\end{array}$ & $\begin{array}{l}-22.654 \\
85.71\end{array}$ \\
\hline
\end{tabular}

${ }^{*}$ t-statistics in parentheses. **Prediction analysis based on 50 percent. 
Table 4

Prediction Errors, Equations 2 and 4

$\underline{\text { Plant }}$

Firm

Predicted $Y$

Actual $\mathrm{Y}$

Equation 2:

Johnstown

Bethlehem

.622

0

Interlake

Interlake

.525

0

Lackawanna

Bethlehem

.002

1

Aliquippa

Jones \& Laughlin

.462

1

Cyclops

Cyclops

.404

1

Equation 4:

Bethlehem

Bethlehem

.684

0

Johnstown

Bethlehem

.889

0

Fairless

United States

.596

0

Riverdale

Interlake

.698

0

Lackawanna

Bethlehem

.107

1

Aliquippa

Jones \& Laughlin

.097

1

Monessen

Wheeling-Pittsburgh

.340

1 


\section{Table 5}

Dependent Variable: FSIZE

$\begin{array}{lc}\text { C } & 10.30 \\ & (1.56) \\ \text { COAST } & 5.87 \\ & (1.02) \\ \text { HEAVY } & 10.99 \\ & (3.18) \\ \text { LG(AGE) } & -2.26 \\ & (-1.42) \\ \text { LG(PSIZE) } & 7.45 \\ & (2.50) \\ \text { EARC } & -1.82 \\ & (-.22)\end{array}$

Adj R SQ: $\quad 0.21$

t-Statistics in parentheses Number of observations: 49. 
Table 6

Dependent Variable: YEAR

(1)

-2.61
$(-.61)$

5.50

(1.29)

$\mathrm{P} 2$ *

$-1.14$

$(-.24)$

P3*

2.01

(.40)

(3)

(4)

$\mathrm{P} 1$ *

$(.09)$

$-4.00$

$(-1.08)$

P4*

.79

(.17)

P4

UNDIV

5.81

(1.65)

5.94

(1.58)

5.86

(1.56)

8.74

(2.16)

D1

2.65
$(1.19)$

3.26

3.30

(1.42)

2.71

(1. 40)

$-4.73$

$-5.24$

-2.29
$(-.55)$

$(-1.30)$

$(-1.18)$

$-1.26$

D2

2.08

1.82

2.01

(.81)

3.86

(.93)

(.76)

.29

(.08)

.05

$(-1.74)$

D4

$-1.44$

(.38)

$(.01)$

$-1.11$

D5

$-4.23$

$-3.43$

$(-1.17)$

$-3.48$

$(-1.18)$

$-4.17$

$(-1.50)$

$-1.42$

$(-.25)$

.22

$(.04)$

5.15

$(.65)$

$-.12$

$-.12$

.19

*Variable Definitions:

PI--closing probability calculated using estimates from table 3 , column 1

P2--closing probabi 1it y calculated using estimates from table 3, column 2

P3--closing probability calculated using estimates from table 3, column 3

P4--closing probability calculated using estimates from table 3 , column 4

t-statistics in parentheses. Number of observations: 21 . 


\section{FOOTNOTES}

1. A firm might actually bolster its threat to maintain capacity during the contraction by refusing to diversify, conveying a clear commitment to the market.

2. One exception to this statement is the collapse of the pipe market following the fall in oil prices. Plants specializing in pipe may have changed their relative standing with respect to expected profits.

3. See Karlson (1983) for selected estimates of plant-specific economies of scale in this industry.

4. Another force would also reduce probability of closing: Closing costs are liable to be much higher for larger plants because of their larger work forces (see Deily, 1988).

5. As an alternative, the number of plants was used instead of raw-steel capacity as a measure of firm size. The estimation results were quite similar.

6. This dummy variable is exactly equal to $D 1$ and to $D A+D C$, and so it is not included in equations 2 and 3 . The coefficients have a different interpretation, however. The coefficient of ONE represents the difference in the probability of closing for plants owned by single-plant firms versus all other plants; the coefficients of the group dummies represent the difference in the probability of closing for plants in each group versus the omitted group (the United States Steel Corporation).

7. Investments in basic oxygen steel furnaces that were made before 1960 were also counted.

8. Interestingly enough, almost all the major mergers involving integrated capacity both before and during the industry's contraction have involved these firms (that is, Wheeling and Pittsburgh in 1968; National and Granite City in 1971; and Jones \& Laughlin and Youngstown Sheet \& Tube in 1978).

9. In these regressions, the OLS estimating procedure was used, as all censored (zero) observations were excluded. 


\section{References}

Barnett, D. E., and R. W. Crandall. Up from the Ashes: The Rise of the Steel Minimill in the United States. Washington, D.C.: The Brookings institution (1986).

Deily, M. E. "Exit Barriers in the Steel Industry." Economic Review. Federal Reserve Bank of Cleveland. (1988) 24(1): 10-18.

- "Investment Activity and the Exit Decision." Review of Economics and Statistics. Forthcoming.

Franklin, P.. "Some Observations on Exit from the Motor Insurance 299-313. Industry, 1966-1972." Journal of Industrial Economics. 22 (1988):

Fudenberg, D. and J. Tirole. "A Theory of Exit in Duopoly." Econometrica 54(4). (1986): 943-960.

Ghemawat, P. "Concentration in Decline." Graduate School of Business Administration, Harvard University. April, 1985.

Ghemawat, P. and B. Nalebuff. "Exit." Rand Journal of Economics 16(2). (1985): 184-194.

Hall, W. K. "Survival Strategies in a Hostile Environment." Harvard Business Review. September/October. (1980): 75-85.

Harrigan, K. R. Strategies for Declining Businesses. Lexington: D. C. Heath and Co. 1980).

Hogan, W. T. Minimills and Integrated Mills: A Comparison of Steelmaking in the United States. Lexington, Massachusetts: Lexington Books, 1987.

- Steel in the United States: Restructuring to Compete.

Lexington, Massachusetts: Lexington Books, 1984.

- The 1970s: Critical Years for Steel. Lexington,

Massachusetts: Lexington Books, 1972.

Institute for Iron and Steel Studies. Steel Plants U.S.A.: Raw Steelmaking Capacities, 1960 and 1973-1980. Greenbrook, New Jersey: Institute for Iron and Steel Studies, 1979.

Karlson, S. H. "Modeling Location and Production: An Application to U. S. Fully-Integrated Steel Plants." Review of Economics and Statistics. 65(1). (1983): 41-50.

Marcus, M. "Firms' Exit Rates and their Determinants. "Journal of Industrial Economics. (November, 1968): 10-22. 
Porter, M. E. Competition Strategy: Techniques for Analyzing Industrial and Competitors. New York: The Free Press, 1980.

Wharton Econometrics. Restructuring and Revival: The World Steel Industry, 1987-2000. Volume III, Part II. Bale Cynwyd, Pennsylvania: Wharton Econometrics, 1987.

Whinston, M. D. "Exit with Multiplant Firms." Harvard Institute for Economic Research Discussion Paper Number 1299. February, 1987. 